\title{
IMPLEMENTASI PENGUATAN DESTINASI PARIWISATA DAERAH MELALUI ANALISIS STRATA DAN PESAING PRODUK UNGGULAN KOTA PEKALONGAN
}

\author{
Andjar Prasetyo \\ Badan Penelitian dan Pengembangan Kota Magelang \\ Email: studidaerah@gmail.com
}

\begin{abstract}
The purpose of the research is to determine and analyze the strata and competitor products, as well as compile options policy recommendations of tourism for the City of Pekalongan. Located in Pekalongan City, from June - November 2021, mix methods with descriptive explorative as a method of research. Secondary Data from the Government of Pekalongan City, the primary data obtained through questionnaires open the 132 respondents and the questionnaire analysis of 56 respondents with Likert scale. Analysis with Three Levels of a Product and the Five Forces. The result strata featured product is batik as a core product, Megono as actual product and Tauto, Coffee as the augmented product, a score between 5-7 points that the products featured on the condition of the potentially claimed as the featured product. The accumulation of the results of the Analysis of Five Forces, that the featured products in support of the tourism are still very in need of strengthening. This research implies that to encourage the increase of tourism in the City of Pekalongan needed to support the strengthening of the featured products on the internal side of the featured products and revamping the external side.
\end{abstract}

Keywords: Featured products, tourism, three levels of a product, five forces

\section{PENDAHULUAN}

Kota Pekalongan memiliki posisi strategis terhadap wilayah sekitarnya dan dalam lalu lintas Pantai Utara Pulau Jawa, dengan budaya khas yang terakulturasi budaya Jawa Pesisir, Arab dan China. Kondisi ini berpotensi untuk dikembangkan sebagai keunggulan komparatif. Keunggulan komparatif Kota Pekalongan, seharusnya mendorong perekonomian dapat berkembang optimal, dengan memanfaatkan pergeseran sektor primer ke sektor sekunder dan tersier, terutama dengan mengembangkan pariwisata. Produk Domestik Regional Bruto (PDRB) Kota Pekalongan Atas Dasar Harga Berlaku menurut Lapangan Usaha tahun 2020 kontribusi terbesar berasal dari Industri Pengolahan sebesar 21,40\%, kemudian Perdagangan Besar dan Eceran; Reparasi Mobil dan Sepeda Motor sebesar 21,16\% dan Kontruksi sebesar $14,6 \%$ dari total PDRB sebesar 10,818.53 Milyar meskipun daya saingnya belum optimal berkembang.

Beberapa hal yang menyebabkan belum berkembangnya daya saing adalah tingkat kunjungan wisatawan masih belum optimal dan semakin rendah karena dampak pandemi Covid-19. Dalam Badan Pusat Statistik (BPS) Kota Pekalongan tercatat penurunan wisatawan menunjukkan kuantitas yang sangat signifikan. Upaya penataan sektor ini pun juga telah dilakukan misalnya KAI (2017) terhadap Kawasan Stasiun KA Pekalongan, BPPKP (2016) untuk kawasan Jetayu dan DPMPTSP Kota Pekalongan (2021) dalam penataan kawasan terminal bus. Beberapa indikator yang menunjukkan belum optimal daya saing Kota Pekalongan seperti yang tercantum dalam Rencana Kerja Pemerintah Daerah (RKPD) Kota Pekalongan Tahun 2022, yaitu pertumbuhan ekonomi pada tahun 2020 berkontraksi sebesar -1,87\%; Rata-rata konsumsi per Rumah Tangga/tahun (Ribu Rp) sebesar Rp.95.282,88; Gini Ratio yang belum mengalami penurunan atau perbaikan; dan belum terkelolanya budaya dengan baik, yaitu persentase seni budaya yang dilestarikan masih terbatas. 
Upaya pemasaran pariwisata yang didefinisikan dalam beberapa literasi seperti Hanafiah \& Zulkifly (2019), Fletcher et al., (2017), Pantano et al. (2017), D’Urso et al., (2016), David Newsome (2013) dan Peraturan Menteri Pariwisata dan Ekonomi Kreatif/ Kepala Badan Pariwisata dan Ekonomi Kreatif Republik Indonesia (2020) dengan adanya Undang-Undang Nomor 10 Tahun 2009 tentang Kepariwisataan, bermuara pada destinasi yang akan dipasarkan dan pesaing/kompetitor destinasi tersebut. Dalam Matias et al., (2016), Diekmann \& Smith (2015), destinasi memiliki produk unggulan yang dapat dipasarkan sebagai daya tarik dan daya saing destinasi berbasis masyarakat yang dijelaskan dalam Hamzah \& Khalifah (2009). Beberapa artikel ilmiah telah memberikan perhatian terhadap pariwisata di Kota Pekalongan namun belum ada yang mengidentifikasi, menganalisis dan mengevaluasi apa yang menjadi produk unggulan baik dari sisi core product, actual product, dan augmented product pariwisata di Kota Pekalongan meskipun beberapa penelitian terdahulu terkait Kota Pekalongan dan pariwisata telah dilakukan, misalnya Sukmasakti \& Hayati (2012), dengan strategi pengembangan wisata batik berdasarkan hasil analisis Analisis Hirarki Proses (AHP) dari aspek promosi, aspek infrastruktur dan aspek kelembagaan. Taufiqurrohman (2013) membahas tentang dampak pariwisata terhadap pendapatan daerah dengan hasil penelitian menunjukkan faktor-faktor pendorong pengembangan obyek wisata. Selanjutnya Damayanti \& Latifah (2015) memberikan analisis upaya pengembangan wisata kreatif bahwa wisata kreatif berbasis batik sangat unik dan memiliki kedudukan yang strategis di Kota Pekalongan. Kemudian dalam Supangkat et al. (2018) menyoroti penataan pemukiman, analisis dengan memanfaatkan teknologi penginderaan jauh dan untuk pemetaan menggunakan software SIG. Metode yang digunakan adalah metode pengharkatan (scoring), tumpang susun (overlay). Dalam Falah (2019) membahas tentang peranan kampung batik. Namun produk yang ditemukan belum secara jelas menunjukkan keunggulannya, disebutkan dalam Kotler et al. (2020) perlu memikirkan produk dan layanan pada tiga tingkatan. Selain hal tersebut perhatian terhadap pesaing juga menjadi perhatian serius, merujuk pada (Porter, 2008), tingkat persaingan dan daya tarik pasar dengan lima kekuatan yang harus dianalisis.

Kuantitas Usaha Kecil Menengah (UKM) banyak terdapat di Kota Pekalongan, dalam data dari Dinas Perdagangan Koperasi, dan UKM Kota Pekalongan pun menunjukkan adanya peningkatan pada tahun 2019 dibandingkan tahun 2018 sebanyak 1.095 unit usaha. Kuantitas tersebut memberikan gambaran bahwa UKM di Kota Pekalongan tumbuh dan berkembang, meski dalam artikel Prasetiani dan Sutrisno (2021) sebanyak 68\% UMKM industri batik mengalami penurunan pendapatan. Namun kuantitas ini belum dapat diketahui apa yang menjadi produk utama Kota Pekalongan selain batik, belum dapat memberikan kejelasan ilmiah tentang strata produk yang dimiliki Kota Pekalongan.

Sejalan dengan hal tersebut maka Kota Pekalongan perlu melakukan kajian dalam menganalisis produk yang dimiliki Kota Pekalongan berdasarkan pendekatan ilmiah. Output kajian memberikan deskripsi strata produk yang dimiliki Kota Pekalongan sehingga dapat digunakan sebagai salah satu alternatif bagi para pemangku kepentingan dalam mengambil kebijakan terkait penanganan produk UKM yang mendorong sektor pariwisata Kota Pekalongan.

Hal ini menjadi penting karena produk pariwisata Kota Pekalongan adalah sesuatu yang dapat ditawarkan ke pasar untuk diperhatikan, dipakai, dimiliki, atau dikonsumsikan sehingga dapat memuaskan keinginan atau kebutuhan. Dengan mengetahui produk unggulan yang tersrata maka pemerintah dapat menentukan kebijakan yang mendorong secara sinergi terhadap produk unggulan terstrata yang memberikan kemudahan yang informatif bagi para konsumen dalam menentukan pilihan pariwisata sekaligus memberikan identitas yang lebih kuat terhadap produk pariwisata di Kota Pekalongan. Dalam pemasaran yang perlu dilakukan dengan cara mengidentifikasi produk unggulan terstrata baik dari sisi core product, actual product, dan augmented product. 
Selanjutnya adalah siapa pesaing baik dari sisi konsumen dan produsen pariwisata di Kota Pekalongan, perlu mengetahui pesaing tersebut dapat dilakukan dengan menentukan intensitas persaingan dalam suatu produk. Dengan mengetahui pesaing maka dapat mengambil kebijakan dalam rangka mendorong percepatan pengembangan pariwisata di Kota Pekalongan.

Dari kondisi tersebut menjadi penting untuk melakukan kajian tentang produk unggulan terstrata dan pesaing yang perlu diperhatikan bagi para pelaku pariwisata di Kota Pekalongan. Dalam prosesnya dibutuhkan identifikasi produk yang terstrata dan bagaimana menangani persaingan internal maupun eksternal di Kota Pekalongan.

Untuk menghasilkan kajian yang dapat dimanfaatkan ini, dibatasi pada bagaimana identifikasi strata produk unggulan dan pesaing produk pariwisata di Kota Pekalongan; bagaimana analisis produk unggulan dan pesaing produk pariwisata di Kota Pekalongan melalui pendekatan Three Level of a Product dan Five Forces; dan apa opsi strategi dan rekomendasi kebijakan yang perlu dilakukan oleh Pemerintah Kota Pekalongan. Tujuan kajian berdasarkan batasan masalah adalah untuk mengetahui strata produk unggulan dan pesaing produk pariwisata di Kota Pekalongan; untuk mengalisis strata produk unggulan dan pesaing produk pariwisata di Kota Pekalongan melalui pendekatan Three Level of a Product dan Five Forces; dan untuk menyusun strategi dan opsi rekomendasi kebijakan yang perlu dilakukan oleh Pemerintah Kota Pekalongan.

\section{METODE PENELITIAN}

Metode kuantitatif diarahkan pada hasil interaksi terhadap responden yang menjadi sampel dalam penelitian ini. Perhatian penelitian kualitatif lebih tertuju pada elemen manusia, objek, dan institusi, serta hubungan atau interaksi di antara elemen-elemen tersebut, dalam upaya memahami suatu peristiwa, perilaku, atau fenomena yang digunakan terhadap diperolehnya kondisi eksisting. Kajian dilaksanakan dengan lokus di Kota Pekalongan. Fokus kajian dilakukan meliputi identifikasi produk unggulan yang selanjutnya analisis menggunakan pendekatan yang telah direncanakan dan menyusun opsi rekomendasi dalam fokus permasalahan yang dihadapi sekaligus sebagai kontribusi dalam pencapaian target pariwisata di Kota Pekalongan. Waktu penelitian dilaksanakan pada bulan Juni sampai dengan November 2021.

Data yang digunakan sebagai pendukung dan referensi dokumen yang mendukung berbagai teori dan konsep yang berasal dari berbagai sumber literatur terdiri dari buku, majalah, media elektronik, dan jurnal ilmiah. Pengumpulan data sekunder dilakukan menggunakan data dari Bappeda; Dinas Perdagangan, Koperasi dan UKM; Dinas Perindustrian dan Tenaga Kerja; Dinas Pariwisata, Kebudayaan, Kepemudaan dan Olahraga terkait tentang data perencanaan pariwisata daerah dan data pelaku UKM Kota Pekalongan. Data primer diperoleh dalam pendalaman dan penajaman hasil analisis melalui kuesioner online bersifat terbuka akibat dampak Pemberlakuan Pembatasan Kegiatan Masyarakat (PPKM) di Jawa Bali. Data primer terdiri dari responden yang berasal dari dalam Kota Pekalongan dan luar Kota Pekalongan dengan waktu pelaksanaan survei mulai tanggal 10 Agustus 2021 sampai dengan 15 Agustus 2021 dengan distribusi dari dalam Kota Pekalongan sebanyak 87 responden dan dari luar Kota Pekalongan sebanyak 45 responden.

Setelah diperoleh produk unggulan yang diketahui oleh responden tersebut kemudian dilakukan survei data primer dengan fokus dalam analisis Three Level of Product dan Five Forces Analysis. Jumlah responden dalam survei kedua sebanyak lima puluh enam responden yang berasal dari Kota Pekalongan. Sampel didasarkan pada penelitian pendekatan perbandingan produk unggulan yang dihasilkan pada survei pertama. Pengumpulan data primer dilakukan secara online karena keterbatasan akses akibat pandemi Covid-19 melalui formulir yang disiapkan dengan tujuan untuk mengidentifikasi produk unggulan yang akan dianalisis dalam kajian ini. Pertemuan yang dihadiri partisipan dengan melakukan penajaman dan penyesuaian konstruktif terhadap substansi sebagai bentuk dari forum diskusi grup digunakan sebagai bagian dari teknik pengumpulan data. 
Teknik analisis data dengan melakukan koordinasi dengan instansi terkait untuk mendapatkan arahan dan kebijakan yang berkaitan dengan kajian; mengidentifikasi permasalahan yang ada terutama masukanmasukan dari stakeholder terkait; melakukan kajian tentang kondisi lokasi kegiatan (analisa Three Level of a Product dan Five Forces); analisis perencanaan terdiri dari a) Tahapan persiapan; b)Tahapan pengumpulan data; dan c) Tahapan survei lapangan; Menyusun instrumen kajian yang memuat Three Level of a Product dan Five Forces dengan kuesioner. Setiap kuesioner menggunakan skala Likert diberikan pilihan sebanyak sembilan jawaban, mulai dari Sangat Rendah yang memiliki skor sebesar 1 poin, Agak Rendah yang memiliki skor sebesar 2 poin, Rendah yang memiliki skor sebesar 3 poin, Sangat Sedang yang memiliki skor sebesar 4 poin, Agak Sedang yang memiliki skor sebesar 5 poin, Sedang yang memiliki skor sebesar 6 poin, Tinggi yang memiliki skor sebesar 7 poin, Agak Tinggi yang memiliki skor sebesar 8 poin dan Sangat Tinggi yang memiliki skor sebesar 9 poin. Pada bagian akhir analisis disajikan dalam bentuk kurva radar untuk memperjelas posisi produk unggulan yang menjadi fokus dalam penelitian ini.

\section{HASIL DAN PEMBAHASAN}

Dalam Indonesia Kaya (2021) masyarakat Kota Pekalongan memang tak bisa lepas dari batik meski tidak ada catatan resmi mengenai kapan batik Pekalongan mulai dikenal. Namun diperkirakan muncul tahun 1800-an dan mengalami perkembangan pesat setelah Perang Jawa atau Perang Diponegoro. Perang memaksa keluarga keraton meninggalkan kerajaan dan menyebar ke daerah-daerah di sebelah Timur dan Barat. Mereka ikut mengembangkan batik yang sebelumnya sudah ada di Pekalongan. Batik Pekalongan (Indonesia Kaya, 2021) termasuk batik pesisiran dari sisi motif, sebenarnya batik Pekalongan mirip dengan batik Solo maupun Yogyakarta. Keunggulan batik Pekalongan terletak pada penggunaan warna. Sehelai kain batik bisa menggunakan delapan warna sehingga terlihat lebih indah dan menarik dibanding batik-batik dari daerah lain. Motif batik Pekalongan umumnya mengambil inspirasi dari flora dan fauna, selain itu akibat akuluturasi budaya, sehingga punya motif batik yang beragam dan luwes. Motif Jlamprang yang menjadi ciri khas batik Pekalongan, misalnya, mendapat pengaruh dari India dan Arab. Batik Encim dan Klengenan dipengaruhi oleh peranakan Cina (Indonesia Kaya, 2021). Batik Pekalongan juga telah menjadi produk yang dideklarasikan sebagai warisan dunia seperti dijelaskan Kartiwa et al. (2014) pasal 7.3 Deklarasi World Batik Summit. Dalam konteks penjualan di Kota Pekalongan, terdapat sentra penjualan batik, salah satunya adalah Pasar Grosir Setono, yang didirikan tahun 1941 yang telah memiliki lebih dari 500 pedagang batik sesuai data dari Dinas Perdagangan, Koperasi dan UKM Kota Pekalongan.

Produk unggulan berikutnya adalah Megono. Megono merupakan salah satu makanan kuliner tradisional nusantara yang berasal dari Kota Pekalongan (Widowati, Hartati, and Amirudin 2018). Sebagai salah satu makanan khas tradisional warisan leluhur, perlu dijaga kelestariannya agar tidak tergeser oleh makanan-makanan modern.

Selanjutnya dalam Panji (2018) disebutkan bahwa Tauto merupakan salah satu kuliner khas Pekalongan. Tauto adalah makanan dari perpaduan dua kebudayaan kuliner (Tionghoa dan India) yang menyatu yang terjadi di Pekalongan. Tauto berasal dari Caudo/Soto kuliner China dan Tauco bumbu India. Sering orang luar kota menyebutnya Soto Tauto Pekalongan. Kuliner ini menjadi salah satu dari produk unggulan yang diklaim di Kota Pekalongan.

Kemudian produk berikutnya adalah produk kopi, meskipun Kota Pekalongan tidak memiliki lahan kopi dalam skala besar namun Kota Pekalongan telah menjadi salah satu daerah yang memanfaatkan kopi sebagai salah satu produk yang digemari penduduknya. Batasan kopi dalam penelitian ini adalah kopi siap saji yang ditunjukkan dengan adanya komunitas kopi, dengan pelaku yang didominasi segmen milenial. Kopi Tjanting dan kopi Tahlil (Panji, 2020) salah satu kopi asli dari Pekalongan. Nama kopi Tahlil diambil dari kebiasaan masyarakat setempat yang menyajikan kopi yang hanya disajikan saat 
acara tahlilan saja hingga dikenal dengan nama kopi Tahlil.

Produk Garang Asem juga merupakan salah satu kuliner yang ada di Kota Pekalongan, dalam artikel Matitaputty \& Kusuma (2017) Garang Asem terbuat dari daging sapi yang diberi tambahan pindang telur ayam yang dibungkus daun pisang dan dikukus. Jika Garang Asem pada umumnya mirip dengan pepes, Garang Asem khas Pekalongan rasanya lebih mirip dengan Rawon, karena ternyata warna kuah yang cokelat berasal dari kluwek yang juga merupakan bumbu dasar Rawon.

\subsection{Penyajian Data Kuesioner Terbuka}

Hasil survei terdapat sebanyak 133 responden yang menjawab kuesioner terbuka, namun dalam jawaban yang digunakan sebanyak 132 responden karena satu responden tidak menyebutkan asal responden. Parameter kuesioner terdiri dari asal responden jenis kelamin responden, lima produk apa saja yang dapat menjadi produk khas Kota Pekalongan ? (Urutan penyebutan menjelaskan peringkat produk) dan mengapa produk tersebut diklaim sebagai produk unggulan di Kota Pekalongan. Deskripsi responden selengkapnya disajikan dalam pembahasan berikut.

Tabel 1 Asal dan Jenis Kelamin Responden

\begin{tabular}{lccc}
\multicolumn{1}{c}{ Uraian } & Laki-laki & Perempuan & Total \\
\hline $\begin{array}{l}\text { Dalam Kota } \\
\text { Pekalongan }\end{array}$ & 56 & 31 & 87 \\
$\begin{array}{l}\text { Luar Kota } \\
\text { Pekalongan }\end{array}$ & 20 & 25 & 45 \\
\hline Grand Total & 76 & 56 & 132 \\
\hline Sumber: Data Primer, 2021 & &
\end{tabular}

Dalam tabel 1 dapat dilihat bahwa 66\% responden berasal dari dalam Kota Pekalongan dengan rincian jenis kelamin laki-laki sebesar 64\% sedangkan jenis kelamin perempuan sebanyak 36\%. Responden berasal dari luar Kota Pekalongan sebanyak 34\%, dengan rincian jenis kelamin laki-laki sebanyak $44 \%$ dan untuk jenis kelamin perempuan terdapat sebanyak $56 \%$.

Kuesioner ini digunakan untuk menunjukkan lima produk yang dapat menjadi produk khas Kota Pekalongan di mana dalam kuesioner dicantumkan pula catatan bahwa urutan penyebutan menjelaskan peringkat produk. Hasil dari kuesioner tersebut memberikan deskripsi bahwa batik merupakan produk yang telah dikenal oleh masyarakat di luar Kota Pekalongan. Berikut disampaikan hasil kuesioner terbuka terhadap produk unggulan yang dimiliki Kota Pekalongan.

Tabel 2 Hasil Kuesioner Terbuka terhadap Produk Unggulan Kota Pekalongan

\begin{tabular}{clll}
\hline No & Peringkat & \multicolumn{1}{c}{ Produk } & \multicolumn{1}{c}{ Respon } \\
\hline 1. & Pertama & Batik & 115 sampel \\
2. & Kedua & Megono & 50 sampel \\
3. & Ketiga & Tauto & 37 sampel \\
4. & Keempat & Kopi & 9 sampel \\
5. & Kelima & Garang Asem & 5 sampel \\
\hline
\end{tabular}

Sumber: Data Primer, 2021

Pada peringkat pertama sebanyak 115 atau sebanyak $87,12 \%$ dari total responden memberikan jawaban produk unggulan pertama di Kota Pekalongan adalah batik, dalam jawaban responden diasumsikan yang termasuk di dalam produk unggulan batik meliputi batik tulis, batik cap, industri tenun, konveksi, tekstil. Respon ini menjelaskan dan menguatkan akan posisi Kota Pekalongan terhadap branding batik telah melekat di masyarakat. Pada peringkat kedua produk unggulan di Kota Pekalongan adalah Megono, dengan jumlah responden yang diperoleh sebanyak 50 sampel atau sebesar $37,88 \%$. Kemudian pada peringkat ketiga produk unggulan di Kota Pekalongan adalah kuliner Tauto, dengan responden yang menjawab sebanyak 37 sampel atau sebesar 28,03\%. Pada peringkat keempat, produk unggulan di Kota Pekalongan adalah kopi, dengan hasil responden sebanyak 9 sampel atau sebesar 6,82\%. Kopi di Kota Pekalongan merujuk pada jawaban responden memiliki kekhasan dalam penyebutanya seperti kopi Tjanting dan kopi Tahlil. Produk unggulan kelima adalah kuliner garang asem dengan respon sebanyak 5 sampel atau sebesar 3,79\%.

Menurut Anda mengapa produk tersebut diklaim sebagai produk unggulan di Kota Pekalongan? Menjadi pertanyaan sederhana yang dapat menunjukkan argumen terhadap produk unggulan yang telah disampaikan responden. Respon terhadap pertanyaan ini merujuk pada indikator kajian yaitu Three Level of a Product secara random yang menjadi bahan analisis selanjutnya. Dalam konteks klasifikasi produk dan layanan dengan indikator 
produk konsumer dan produk industri produk batik telah memenuhi unsur dimaksud tercermin dari respon jawaban terhadap pertanyaan yang disampaikan. Indikasi tersebut ditandai dengan beberapa jawaban yang telah disesuaikan secara redaksional namun tidak merubah substansi misalnya :

a. Dari zaman dulu batik menjadi ikon Kota Pekalongan, letak Kota Pekalongan tidak jauh dari pantai Utara, Banyak produk batik dan koveksi, sebagai penyangga ibu kota negara dan ibu kota provinsi banyak produk industri rumah tangga yang telah dipasarkan. Memiliki tingkat produksi dan value added, multiplier effect dan nilai permintaan produk yang tinggi.

b. Ada khas tersendiri, banyak dicari oleh warga asli maupun wisatawan, banyak diminati tidak hanya oleh warga Pekalongan. Banyak perusahaan yang bergerak di bidang tersebut. Batik dan sarung tenun dari Pekalongan merupakan produsen terbesar, mangrove dan pantai Pekalongan merupakan kota pesisir, kuliner (Pekalongan memiliki kuliner yang tidak dimiliki daerah lain).

\subsection{Penyajian Data Analisis Strata Produk Dan Analisis Pesaing Produk}

Data analisis secara umum dapat dijelaskan bahwa responden terdapat lima puluh enam responden. Jumlah responden didasarkan pada perbandingan antar produk unggulan yang menjadi fokus penelitian. Lima puluh enam responden memberikan jawaban terhadap kuesioner yang terbagi dalam tiga kelompok. Kelompok kuesioner pertama merupakan kuesioner administratif, kelompok kuesioner kedua adalah substansi Five Forces dan kelompok terakhir adalah kelompok Three Level of a Product. Pada kelompok pertama berupa data administratif yang menjelaskan karakter responden dalam beberapa indikator.

Sebanyak 70 persen responden berjenis kelamin perempuan, hal ini sejalan dengan penelitian yang dilakukan oleh Fitriani (2019) yang menjelaskan bahwa kaum perempuan memiliki kecenderungan lebih mudah mengambil keputusan pembelian untuk produk dan dikuatkan Basith and Fadhilah (2019) meskipun berbeda dengan hasil penelitian dari
Sosianika dan Juliani (2017) bahwa tidak terdapat perbedaan perilaku pembelian impulsif berdasarkan jenis kelamin. Jenis kelamin lakilaki yang memberikan respon sebesar 30\% dari total responden.

Hasil survei memberikan deskripsi secara administratif tentang responden dalam analisis strata produk dan pesaing produk yang terdiri dari nama, nomor handphone, klaim produk unggulan, pekerjaan, pendidikan, jenis kelamin, pengetahuan tentang Five Forces dan Three Level of a Product.

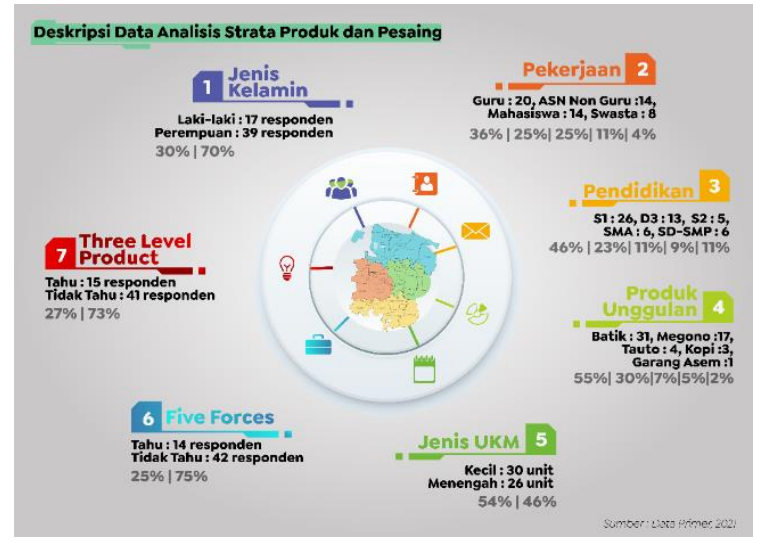

Gambar 1 Deskripsi Data Analisis Strata Produk dan Analisis Pesaing Produk

Dalam indikator pekerjaan didominasi oleh responden yang telah memiliki penghasilan baik Aparatur Sipil Negara (ASN), guru dan swasta meskipun mahasiswa juga memiliki kemampuan dalam membeli produk unggulan dalam fokus penelitian ini. Indikator pekerjaan ini relevan dengan hasil studi Basith dan Fadhilah (2019) yang menjelaskan mengidentifikasi karakteristik konsumen dengan salah satu komponennya adalah keputusan membeli dari jenis pekerjaan yang dimiliki responden.

Dalam konteks pendidikan dapat ditunjukkan dari hasil responden memiliki dominasi di tingkat pendidikan tinggi, merujuk penelitian Wahyuni dan Zuhriyah (2020), pendidikan memiliki hasil dalam penentuan terhadap produk unggulan yang diminati/dibeli. Dominasi responden berpendidikan sarjana (S1) sebanyak 46\%, meskipun terendah namun responden berpendidikan S2 juga ada yang merespon kuesioner yang disampaikan.

Dalam asumsi responden sebanyak 54\% menyebutkan bahwa produk unggulan Kota 
Pekalongan termasuk dalam jenis UKM kecil sedangkan sebanyak $46 \%$ merupakan UKM menengah. Salah satu pertanyaan untuk responden yang harus dijawab adalah pengetahuan analisis yang digunakan dalam studi ini. Hasilnya menunjukkan seperempat (25\%) jumlah responden tahu dan tiga per empat $(75 \%)$ jumlah responden tidak tahu tentang Three Level of a Product. Sejalan dengan Three Level of a Product, responden sebanyak $24 \%$ tahu dan $76 \%$ lainnya tidak tahu tentang analisis ini.

\subsection{Analisis Strata Produk Unggulan}

Analisis diawali dengan produk batik dengan jawaban sebanyak 31 respon, megono dengan jawaban sebanyak 17 respon dan analisis terhadap seluruh respon yang menjelaskan posisi produk unggulan Kota Pekalongan. Pada akhir analisis dilakukan akumulasi terhadap keseluruhan produk unggulan dalam kajian ini.

\subsubsection{Batik Kota Pekalongan}

Produk ini memiliki klaim yang kuat karena dari pendekatan histori telah muncul dan menjadi salah satu pusat perkembangan batik di Indonesia seperti dijabarkan dalam beberapa literasi dalam bab empat ini. Batik dalam analisis ini memiliki respon sebanyak 31 jawaban, dapat diasumsikan bahwa batik merupakan produk yang mendukung pengembangan pariwisata. Oleh karena itu batik menjadi penting untuk dilakukan analisis strata produk.

Pada kurva di bawah ini dapat dilihat bahwa lini produk penjual terhadap produk unggulan batik belum sepenuhnya tertata yang ditunjukkan dengan skor 5,84 poin, selanjutnya konsumen, produsen belum secara lengkap memahami bauran produk (harga paket terhadap produk tertentu) penjual terhadap produk unggulan batik yang ditunjukkan dengan skor 5,97 poin. Selain kedua indikator tersebut meskipun skor telah mencapai lebih dari 6 namun belum secara maksimal karena batik masih merupakan produk yang diketahui seperlunya.

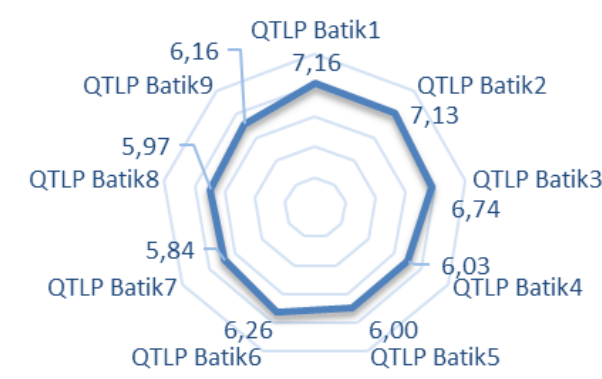

Sumber : data primer diolah, 2021

Gambar 2 Kurva Radar Analisis Strata Produk Unggulan Batik Kota Pekalongan

Upaya dalam mendorong produk unggulan batik sebagai salah satu produk yang mendukung pariwisata dengan menguatkan pemahaman konsumen bahwa batik sebagai produk konsumen dengan memperhatikan aspek yang meliputi produk kenyamanan, produk belanja, produk khusus, dan produk yang tidak dibeli. Batik sebagai produk industri untuk diproses lebih lanjut dalam menjalankan usaha. Kebutuhan organisasi yang berisi produsen/penjual dengan tempat yang lebih representatif tersrata dan memiliki gagasan yang dinamis menyesuaikan kebutuhan pasar.

Selain hal tersebut upaya batik dalam menjadi produk unggulan Kota Pekalongan diperlukan pemahaman terhadap produsen batik terhadap aspek sebagai berikut

a. Atribut produk batik seperti kualitas, fitur, gaya, dan desain yang terdokumentasi dengan baik dan teratur.

b. Pengelolaan branding batik Kota Pekalongan baik secara parsial maupun umum karena konsumen memandang merek sebagai bagian penting dari suatu produk, dan pencitraan merek dapat menambah nilai pada pembelian konsumen. Merek menjadi dasar di mana keseluruhan cerita dapat dibangun tentang kualitas suatu produk.

c. Pengemasan, pelabelan dan logo, berkisar dari tag sederhana yang dilampirkan pada produk hingga grafik kompleks yang merupakan bagian dari kemasan. Aspek ini diperlukan pengelolaan secara teratur dan berkelanjutan.

d. Layanan dukungan, fasilitas layanan produk batik, dipenuhi dengan survei secara berkala untuk menilai layanan dan mendapatkan ide untuk layanan baru. 
Dalam praktiknya Museum Batik (Falah, 2018) sebagai salah satu implementasi fasilitas layanan produk batik di Kota Pekalongan terhadap konsumen.

e. Keputusan lini produk, sekelompok produk batik yang terkait erat dalam satu rantai pasokan dari hulu hingga hilir karena fungsinya serupa berada dalam kisaran harga tertentu.

f. Keputusan bauran produk batik dari semua lini produk batik dan satuan yang ditawarkan penjual tertentu untuk dijual yang dikoordinasikan oleh organisasi yang menangani produk batik.

g. Pemasaran jasa, yang mengacu pada kualitas layanan dengan bergantung pada siapa yang menyediakan batik, kapan batik dijual, di mana batik diperoleh, dan bagaimana layanan batik disediakan.

\subsubsection{Megono Kota Pekalongan}

Produk unggulan kedua yang dapat diklaim sebagai produk aktual dalam strata produk adalah kuliner nasi Megono. Hasil tabulasi secara rinci terlampir dalam kajian ini pada halaman lampiran dengan respon yang diperoleh sebanyak 17 jawaban dengan perlakuan analisis sama dengan produk unggulan batik. Hasil tabel strata produk Megono Kota Pekalongan kemudian disajikan dalam bentuk kurva radar. Kurva radar diskenario dengan baseline sebesar 9 poin sebagai batas maksimal seperti pada gambar berikut

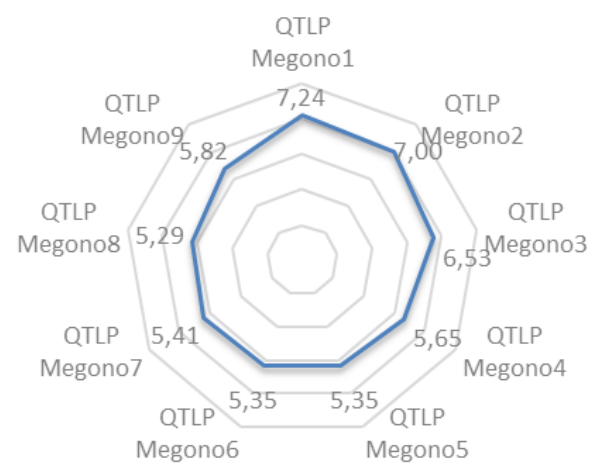

Sumber : data primer diolah, 2021

Gambar 3 Kurva Radar Analisis Strata Produk

Unggulan Megono Kota Pekalongan

Pada kurva tersebut dapat dilihat kelemahan produk unggulan Megono dari nilai pada bauran produk (harga paket terhadap produk tertentu) penjual/pemasok terhadap produk unggulan Megono yang ditunjukkan dengan skor terendah sebesar 5,29 poin, selanjutnya kelemahan kedua branding, pengemasan, pelabelan terhadap produk unggulan megono dan layanan dukungan produk, fasilitas layanan produk terhadap produk unggulan megono yang ditunjukkan dengan skor 5,35 poin. Padahal Megono telah sering dinikmati sebagai produk konsumen dan dilakukan sebagai sebuah kebiasaan yang dinyatakan dalam skor yang dinyatakan telah mencapai nilai minimal 7 poin. Hal ini dapat dinyatakan bahwa Megono pada dasarnya dapat digunakan sebagai produk aktual yang mendorong peningkatan pariwisata di Kota Pekalongan dengan meningkatkan aspek-aspek yang memiliki skor di bawah 6 poin.

Upaya dalam mendorong produk unggulan Megono sebagai salah satu produk yang mendukung pariwisata dengan menguatkan pemahaman konsumen/penjual/penyedia Megono bahwa Megono sebagai produk konsumen dengan menata lebih baik aspek kenyamanan, produk belanja, produk khusus, dan produk yang tidak dibeli. Megono sebagai produk yang dapat disediakan berkelanjutan karena respon pembelian berulang. Pentingnya organisasi yang berisi produsen/penjual dengan tempat yang lebih representatif tersrata dan memiliki gagasan yang dinamis menyesuaikan kebutuhan pasar.

Selain hal tersebut diperlukan pemahaman terhadap produsen/penjual Megono terhadap aspek sebagai berikut :

a. Kualitas, fitur, gaya, dan desain yang terdokumentasi dengan baik dan teratur atribut produk Megono seperti seperti pada produk unggulan inti batik Kota Pekalongan yang telah diakui nasional dan global.

b. Pengelolaan branding Megono Kota Pekalongan baik secara parsial maupun umum karena konsumen memandang Megono sebagai bagian penting dari suatu produk unggulan Kota Pekalongan sehingga dibutuhkan pencitraan yang dapat menambah nilai pada pembelian konsumen terhadap Megono.

c. Aspek pengemasan, pelabelan dan logo serta pemasaran jasa diperlukan 
pengelolaan secara teratur dan berkelanjutan. Proses ini dapat menggunakan interaksi media sosial yang memberikan dampak penguatan produk unggulan Megono.

d. Layanan dukungan, fasilitas layanan produk megono, yang dapat dipenuhi dengan melakukan survei kepada secara berkala untuk menambah pemahaman, penguatan dan mendapatkan ide untuk layanan baru.

e. Dipasarkan melalui lokasi yang sama, atau berada dalam kisaran harga tertentu yang disepakati.

f. Keputusan bauran produk megono dari semua lini produk Megono dan satuan yang ditawarkan penjual tertentu untuk dijual yang dikoordinasikan oleh organisasi yang menangani produk Megono.

\subsubsection{Produk Unggulan Kota Pekalongan}

Pada analisis produk unggulan ini menyajikan akumulasi dari produk unggulan yang telah direspon dalam jawaban. Argumen analisis ini memberikan pemahaman secara umum tentang strata produk yang dimiliki oleh Kota Pekalongan yang terdiri dari Batik, Megono, Tauto, Kopi dan Garang Asem.

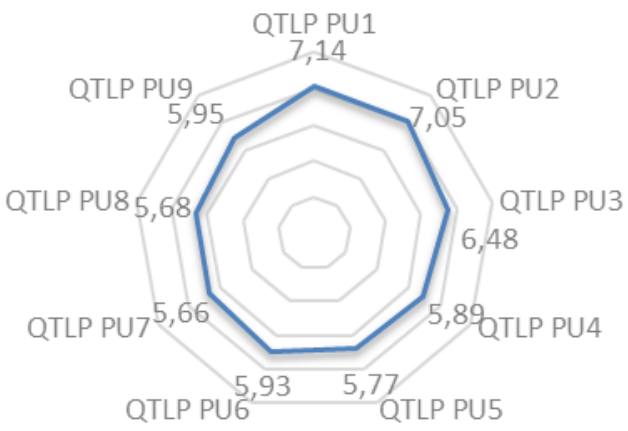

Sumber : data primer diolah, 2021

Gambar 4 Kurva Radar Analisis Strata Produk Unggulan Kota Pekalongan

Upaya dalam mendorong produk unggulan sebagai salah satu produk yang mendukung pariwisata dengan menguatkan pemahaman bahwa :

a. Aspek kenyamanan, produk belanja, produk khusus, dan produk yang tidak dibeli terhadap lima produk sebagai produk konsumen perlu dilakukan penataan lebih baik.

b. Produk diharapkan dapat disediakan secara berkelanjutan karena respon pembelian berulang, sebagai bagian dari upaya mendorong Kota Pekalongan menjadi destinasi pariwisata.

c. Adanya organisasi yang berisi produsen/penjual dengan tempat yang lebih representatif tersrata dan memiliki gagasan yang dinamis menyesuaikan kebutuhan pasar dapat digunakan sebagai media yang mengelompokkan kelima produk, sehingga semakin kuat dan terlihat jelas strata produk unggulan Kota Pekalongan dalam mendorong sektor pariwisata.

Selain hal tersebut upaya batik dalam menjadi produk unggulan Kota Pekalongan diperlukan pemahaman lima produk terhadap aspek sebagai berikut :

a. Pendokumentasian produk unggulan ini yang berisi atribut produk seperti kualitas, fitur, gaya, dan desain dengan baik dan teratur dapat memperkuat keberadaan lima produk.

b. Pencitraan melalui pengelolaan branding lima produk baik secara parsial maupun umum karena konsumen memandang produk tersebut sebagai bagian penting dari suatu produk unggulan Kota Pekalongan.

c. Pengemasan, pelabelan, layanan dukungan, fasilitas layanan produk, keputusan bauran produk, dan pemasaran jasa dalam mendukung keputusan lini produk sangat penting. Aspek ini diperlukan pengelolaan secara teratur dan berkelanjutan.

Hasil analisis ini menunjukkan bahwa produk unggulan Kota Pekalongan pada dasarnya telah memiliki strata produk yang tertata, namun agar dapat menjadi salah satu komponen yang mendukung pengembangan sektor pariwisata dibutuhkan upaya yang dilakukan dari hulu hingga hilir utamanya pada atribut, layanan dukungan produk, lini produk, bauran produk, layanan terhadap produk unggulan. Di samping itu penawaran produk, kebijakan pemerintah, tenaga kerja, tuntutan kualitas, standardisasi dan harga masih 
memerlukan pembenahan agar menjadi produk unggulan yang mendukung pariwisata. Pelaksanaan secara teknis dapat berupa bantuan peningkatan kapasitas dan kemampuan pelaku produk unggulan daerah tentang desain produk, tata letak produksi dan penanganan bahan material, proses desain, kontrol kualitas, kontrol produksi dan perencanaan, manajemen bahan, manajemen pemeliharaan, standardisasi dan harga produk unggulan daerah.

\subsection{Analisis Pesaing}

Pada pembahasan analisis pesaing dilakukan seperti dalam analisis strata produk, pada pembahasan awal dilakukan terhadap produk batik, kemudian dilanjutkan dengan produk Megono dan pada akhir pembahasan analisis pesaing disajikan akumulasi produk unggulan Kota Pekalongan. analisis pesaing didasarkan pada lima komponen yang meliputi 1) Ancaman masuk; 2) Hambatan untuk masuk; 3) Kekuatan pemasok; 4) Kekuatan pembeli; dan 5) Ancaman pengganti. Hasil analisis pesaing telah disajikan dalam bentuk akumulasi setiap parameter yang terdapat dalam lima komponen dan dilengkapi dengan kurva radar.

\subsubsection{Analisis Pesaing Produk Unggulan Batik}

Analisis Pesaing ini memiliki manfaat dalam rangka menunjukkan potensi dan kenyataan yang muncul terhadap pemasaran batik baik secara langsung maupun tidak langsung. Hal ini menjadi perhatian yang penting karena daerah penghasil batik selain Kota Pekalongan yang bermunculan.

Hasil pengukuran dapat dilihat bahwa ratarata potensi pesaing masih muncul, ditunjukkan dari skor yang diperoleh berada di antara 6,38 poin sampai 6,9 poin. Setelah diawali dengan hasil standard deviasi sedangkan dalam hasil kuesioner ini tidak terdapat deviasi antar jawaban karena menghasilkan nilai deviasi antara 0,56 - 0,94 (di bawah 5). Pada median dan modus menunjukkan nilai yang sama dengan batasan hasil berada pada posisi 6,886,33 poin hal ini menunjukkan bahwa batik meskipun telah dapat diklaim sebagai produk unggulan Kota Pekalongan masih memiliki kelemahan dalam lima komponen yang akan dijelaskan lebih lanjut pada kurva radar.
Kurva radar analisis pesaing produk unggulan batik Kota Pekalongan menunjukkan nilai perolehan antara 6,38 poin $-6,90$ poin. Kondisi ini menunjukkan keadaan bahwa secara keseluruhan meskipun telah diakui batik sebagai produk unggulan Kota Pekalongan, namun dalam pesaing membutuhkan strategi untuk lebih baik dan mempertahankan produk.

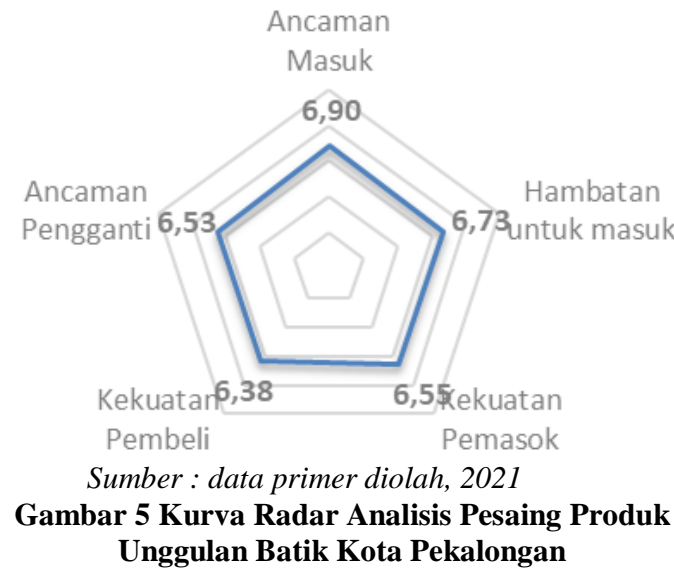

Nilai tertinggi ditunjukkan pada komponen ancaman masuk sebesar 6,9 poin memberikan makna bahwa batik memiliki persaingan yang sedang menuju tinggi karena banyak penyedia batik. Hal ini terjadi ketika industri batik tumbuh akibat konstruksi budaya dan konsumen dapat dengan mudah beralih ke penawaran pesaing dengan biaya rendah untuk mendapatkan batik. Nilai hambatan untuk masuk ditunjukkan sebesar 6,73 poin yang masuk dalam batasan antara sedang dan tinggi dalam mengembangkan produk unggulan batik. Bagian ini menjelaskan tentang seberapa sulit bagi pendatang baru untuk memasuki pasar produk batik. Kekuatan produsen batik dipengaruhi oleh kekuatan pendatang produsen batik baru. Kekuatan-kekuatan tersebut dipengaruhi oleh hambatan berupa biaya masuk, regulasi, kondisi ekonomi, hak paten, dan lainnya yang ada di sekitar. Bila hambatan bagi pendatang produsen batik baru untuk memasuki pasar atau industri cukup banyak, kekuatan pendatang produsen batik baru akan lemah dan kekuatan produsen batik akan kuat. Sedangkan ketika hambatan bagi pendatang produsen batik baru cukup sedikit dan rendah, kekuatan bagi produsen batik akan melemah dan justru menguatkan kekuatan pendatang produsen batik baru. 
Kekuatan produsen batik memperoleh skor sebesar 6,55 poin, hal ini dikuatkan dengan adanya produsen batik dari luar Kota Pekalongan yang memasarkan produknya di Kota Pekalongan. Produsen batik selaku pemasok bahan baku batik memiliki kekuatan tawar-menawar yang berbeda. Kemampuan penyedia bahan baku dalam menentukan syarat atau perjanjian kerja sama dengan produsen/penjual batik sangat berpengaruh bagi kekuatan masing-masing pihak.

Kekuatan pembeli sebesar 6,38 poin menunjukkan posisi batik diterima dalam batasan sedang oleh para pembelinya. Pembeli batik memiliki peran yang sangat penting. Kemampuan yang dimiliki pembeli batik untuk menawar dan mendorong harga produk batik lebih rendah adalah salah satu dari lima kekuatan yang mempengaruhi produk batik.

Ancaman pengganti sebesar 6,53 poin memberikan deskripsi dalam batasan sedang menuju tinggi. Kekuatan dan persaingan produsen batik tak hanya muncul dari pendatang baru dan kompetitor, melainkan juga datang dari barang atau produk pengganti, misalnya pakaian modern dan sejenisnya.

\subsubsection{Analisis Pesaing Produk Unggulan Megono}

Hasil respon terhadap produk Megono diperoleh sebanyak 17 jawaban yang dianalisis. Rata-rata jawaban responden berada pada skor di bawah nilai 6 poin, antara 5,92 poin sampai 5,62 poin. Kondisi ini secara umum memiliki makna belum sepenuhnya dapat diklaim sebagai produk unggulan Kota Pekalongan karena posisi produk Megono dapat dengan mudah ditemui selain di Kota Pekalongan oleh karena itu dibutuhkan penelitian lebih lanjut agar Megono dapat diklaim sebagai produk unggulan Kota Pekalongan yang dapat mendukung sektor pariwisata Kota Pekalongan.

Nilai pada ancaman masuk produk Megono diperoleh sebesar 5,92 poin yang berarti pada kondisi sedang. Ancaman masuk terhadap produk Megono yang sedang akan mengakibatkan produk Megono mengalami penurunan profitabilitas dengan cepat karena semakin meningkatnya persaingan di antara penjual Megono sebagai produk yang mendukung sektor pariwisata.

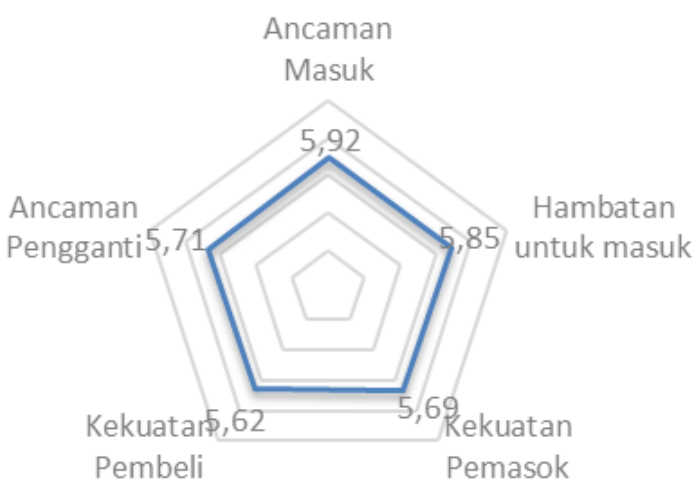

Sumber : data primer diolah, 2021

Gambar 6 Kurva Radar Analisis Pesaing Produk Unggulan Megono Kota Pekalongan,

Hambatan masuk ditunjukkan dengan skor sebesar 5,85 poin berada pada posisi sedang yang berarti masih dalam batasan yang dapat diminimalisir agar produk Megono dapat berkembang sebagai produk unggulan yang mendukung sektor pariwisata di Kota Pekalongan.

Kekuatan pemasok/penyedia produk Megono memiliki hasil pengukuran sebesar 5,69 poin memberikan makna posisi pemasok/penyedia menurut jawaban responden masih terbatas/sedang. Kesiapan rantai pasokan bahan baku dari penjual produk Megono menjadi bagian penting dalam proses produksi Megono.

Kekuatan pembeli masih rendah dengan hasil sebesar 5,62 poin, artinya masih ada potensi pembeli yang dapat direspon terhadap produk Megono. Salah satu kunci utama dalam mencapai keberlangsungan produk Megono ditentukan oleh kekuatan pelanggan.

Ancaman pengganti menunjukkan hasil yang rendah yaitu sebesar 5,71 poin memberikan kondisi sedang, yang mencirikan Megono masih dapat diunggulkan menjadi produk pendukung pariwisata di Kota Pekalongan.

\subsubsection{Analisis Pesaing Produk Unggulan}

Hasil pengukuran menunjukkan rata-rata produk unggulan Kota Pekalongan ini masih dalam posisi sedang menuju tinggi untuk memenuhi kebutuhan sebagai produk pendukung sektor pariwisata, ditunjukkan dengan skor yang diperoleh sebesar 6,48 poin untuk ancaman masuk, sebesar 6,39 poin untuk 
hambatan untuk masuk, sebesar 6,16 poin untuk kekuatan pemasok, sebesar 6,08 poin untuk kekuatan pembeli, dan sebesar 6,22 untuk ancaman pengganti.

Selanjutnya untuk standard deviasi memiliki nilai sebesar 1,03 sampai 1,11 (dibawah 5) memberikan pemahaman bahwa responden secara umum memahami dan mengenal produk unggulan tersebut sebagai produk yang telah ada di Kota Pekalongan. Sementara itu untuk median setelah diakumulasi berada pada jawaban sedang dengan nilai yang diperoleh sebesar 6,63 sampai 6,20. Seperti halnya median pada modus memperoleh skor sebesar 6,00 yang termasuk dalam kategori sedang.

Pada kurva radar tersebut kelima komponen memiliki kelemahan untuk membentuk lima produk menjadi produk unggulan Kota Pekalongan sebagai pendukung sektor pariwisata. Hal ini ditunjukkan pada nilai yang diperoleh berada pada kisaran 6,08 poin sampai dengan 6,48 poin yang berarti pada posisi sedang.

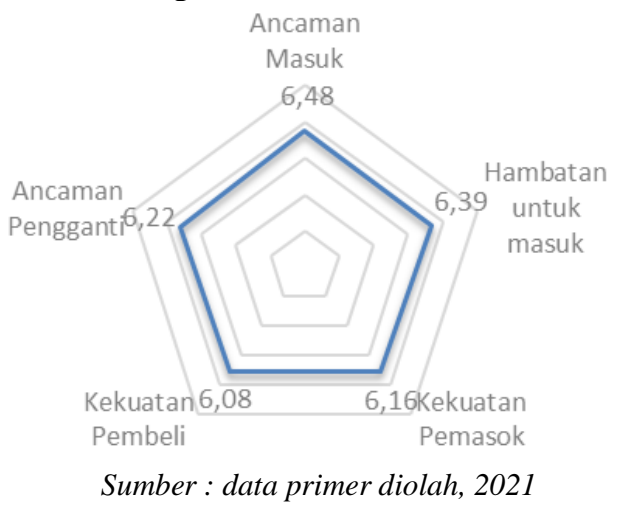

Gambar 7 Kurva Radar Analisis Pesaing Produk Unggulan Kota Pekalongan

Pada ancaman masuk memiliki skor tertinggi meski masih dalam batasan sedang, oleh karena itu dibutuhkan upaya bersama dalam mengantisipasi agar lima produk dapat menjadi produk yang diunggulkan dalam mendukung sektor pariwisata. Dalam kajian ini beberapa hal yang perlu diperhatikan di antaranya perlunya informasi biaya produksi secara keseluruhan, berkala dan berkelanjutan; kematangan produk yang dapat disediakan dalam jumlah kecil atau harus dalam jumlah yang besar; ketersediaan variabel tidak langsung misalnya kekayaan intelektual, kemudahan akses ke bahan baku, hak pengelolaan/perijinan, kemudahan dari pemerintah termasuk antisipasi; ketersediaan modal yang dibutuhkan; dan potensi munculnya pertumbuhan lima produk.

Komponen kedua adalah hambatan untuk masuk yang mendapatkan skor sebesar 6,39 poin menempati posisi sedang, yang artinya hambatan yang ditemukan masih dalam batasan yang dapat diselesaikan oleh para pelaku lima produk, namun perlu memperhatikan beberapa hal dalam rangka mengantisipasi adanya hambatan untuk masuk sebagai berikut : Pertumbuhan lima produk baik yang ada di dalam maupun dari luar Kota Pekalongan; Posisi Kota Pekalongan yang memudahkan pemasaran produk dari daerah luar Kota Pekalongan; Dominasi dinamis dari perkembangan produk membutuhkan diferensiasi menjadi salah satu isu yang perlu direspon oleh pelaku, dunia pendidikan, media massa, masyarakat dan pemerintah; Kapasitas dan kemampuan pelaku produk unggulan membutuhkan identitas merek penting dilakukan sebagai penguat produk dalam proses mendukung sektor pariwisata; Penataan konsentrasi, keseimbangan ketersediaan produk, kompleksitas informasi dalam mendorong penguatan produk; dan Keragaman pesaing yang berasal dari luar Kota Pekalongan yang perlu diantisipasi dengan kebijakan pemerintah.

Komponen ketiga dalam kajian ini adalah kekuatan pemasok dengan skor yang diperoleh sebesar 6,16 poin bermakna sama dengan komponen sebelumnya dalam posisi sedang. Pemasok dalam beberapa proses masih belum tersedia secara lengkap dan variatif. Oleh karena itu dibutuhkan beberapa upaya seperti diferensiasi input, kehadiran input, konsentrasi pemasok; adanya kepastian kebutuhan dalam kuantitas volume; dan dampak input pada biaya atau diferensiasi produk sebagai pendukung keberlangsungan produk.

Kekuatan pembeli memperoleh skor sebesar 6,08 poin. Kondisi ini merupakan hasil pengukuran terendah yang dimaknai bahwa pembeli/konsumen memiliki kuantitas yang masih dapat ditingkatkan dengan memperhatikan beberapa hal seperti 
mengetahui konsentrasi, volume, integrasi, produk pengganti, ukuran harga/total, perbedaan produk yang muncul, identitas merek, skema keuntungan pembeli yang dapat dinikmati dan insentif pembuat keputusan dalam hal ini pemerintah untuk memberikan setidaknya stimulan terhadap kelima produk.

Ancaman pengganti dengan skor yang diperoleh dari hasil pengukuran sebesar 6,22 poin, memberikan makna dalam posisi sedang, sehingga memberikan potensi yang lebih tinggi dalam pengembangan sebagai produk unggulan dalam mendukung sektor pariwisata di Kota Pekalongan dengan antisipasi persaingan dari luar Kota Pekalongan lainnya dari berbagai sisi harga, kualitas, ketersediaan, lokasi, kemudahan maupun kuantitas. Ketika tidak memiliki substitusi dekat, maka kekuatan untuk menaikkan harga dan mengunci persyaratan yang menguntungkan menjadi lebih besar.

Dari hasil analisis pesaing produk unggulan Kota Pekalongan ini dapat diketahui bahwa produk Batik, Megono, Taoto, Kopi dan Garang Asem dari Kota Pekalongan apabila akan diklaim sebagai produk yang dapat mendukung sektor pariwisata di Kota Pekalongan membutuhkan perhatian dalam mengantisipasi munculnya ancaman masuk dan hambatan untuk masuk, di samping itu membutuhkan upaya dalam merespon kekuatan pembeli dan kekuatan penjual produk unggulan dari sisi penawaran produk, kebijakan pemerintah, tenaga kerja, tuntutan kualitas, standardisasi dan harga masih memerlukan pembenahan agar menjadi produk unggulan.

\section{KESIMPULAN}

Berdasarkan hasil kuesioner terbuka tentang produk unggulan dan kuesioner analisis bahwa strata produk unggulan dan pesaing produk unggulan Kota pekalongan yang dapat diketahui dari hasil penelitian ini terdiri dari produk inti yaitu Batik, produk aktual yaitu Megono dan produk pendukung lainnya diasumsikan Taoto, Kopi dan Garang Asem.

Hasil analisis strata produk menggunakan dengan Three Level of Product memperoleh skor sebesar 5-7 poin yang menjelaskan bahwa produk unggulan tersebut masih pada kondisi sedang seperti dalam parameter analisis, maknanya produk Batik, Megono, Taoto, Kopi dan Garang Asem pada dasarnya telah memiliki strata produk yang tertata, namun agar dapat menjadi salah satu komponen yang mendukung pengembangan sektor pariwisata dibutuhkan upaya penguatan yang dilakukan dari hulu hingga hilir.

Untuk analisis Five Forces, menjelaskan bahwa produk unggulan dalam mendukung pariwisata masih sangat membutuhkan penguatan dari berbagai sisi. Diketahui bahwa produk Batik, Megono, Taoto, Kopi dan Garang Asem dari Kota Pekalongan apabila akan diklaim sebagai produk yang dapat mendukung sektor pariwisata di Kota Pekalongan membutuhkan perhatian dalam mengantisipasi munculnya ancaman masuk dan hambatan untuk masuk, di samping itu membutuhkan upaya dalam merespon kekuatan pembeli dan kukuatan penjual/produsen/penyedia produk unggulan Kota Pekalongan.

Implikasi penelitian ini menjelaskan bahwa untuk mendorong peningkatan pariwisata di Kota Pekalongan dibutuhkan dukungan produk unggulan. Dukungan produk yang dapat berkontribusi dalam pengembangan pariwisata berupa Batik, Megono, Taoto, Kopi dan Garang Asem. Upaya yang direkomendasikan utamanya pada penguatan atribut, layanan dukungan, lini produk, bauran produk, layanan penjual terhadap produk unggulan. Di samping itu penawaran produk, kebijakan pemerintah, tenaga kerja, tuntutan kualitas, standardisasi dan harga masih memerlukan pembenahan agar menjadi produk unggulan yang mendukung pariwisata. Opsi rekomendasi disampaikan dalam dua bagian yaitu :

Opsi rekomendasi kebijakan terdiri dari perlunya penyusunan kebijakan/hukum; perlunya penetapan mekanisme kelembagaan untuk melaksanakan kebijakan produk unggulan daerah; perlunya implementasi dan evaluasi program penguatan; perlunya penetapan organisasi yang menangani produk unggulan daerah yang mendukung sektor pariwisata (lembaga terkait pemerintah, LSM, independen); perlunya praktik penetapan standar yang baik; perlunya penetapan rencana strategis; perlunya penetapan keterampilan manajemen dan kepemimpinan; dan perlunya 
penetapan manajemen teknologi informasi produk unggulan daerah yang mendukung sektor pariwisata.

Opsi rekomendasi teknis terdiri dari perlunya pelaksanaan, pengembangan, penerapan dan evaluasi kebijakan; perlunya pelaksanaan praktik pengembangan standar produk unggulan daerah; perlunya pelaksanaan penelitian dan pengembangan; perlunya pelaksanaan pelatihan pengembangan standar produk unggulan daerah; perlunya pelaksanaan pelatihan penilaian risiko produk; perlunya pelaksanaan, pengembangan, implementasi, dan penilaian konsumen; perlunya pelaksanaan bantuan teknis tentang desain produk, tata letak produksi dan penanganan bahan material, proses desain, kontrol kualitas, kontrol produksi dan perencanaan, manajemen bahan, manajemen pemeliharaan, standardisasi dan harga produk; perlunya pelaksanaan rencana kerja oleh struktur kelembagaan; perlunya pelaksanaan sistem manajemen informasi produk unggulan; perlunya pelaksanaan kepemimpinan dan manajemen; dan perlunya pelaksanaan jaringan dan keterlibatan pemangku kepentingan dalam perlindungan konsumen dan produk unggulan daerah yang mendukung sektor pariwisata.

\section{REFERENSI}

Basith, A., \& Fadhilah, F. (2019). Analisis Faktor-Faktor yang Mempengaruhi Keputusan Pembelian Produk pada McDonald's di Jatiasih Bekasi. Jurnal Manajemen Dan Organisasi, 9(3), 192203.

https://doi.org/10.29244/jmo.v9i3.28224

BPPKP. (2016). Kawasan Budaya Jetayu. Badan Promosi Pariwisata Kota Pekalongan.

http://tourism.pekalongankota.go.id/destin asi/7-Kawasan Budaya Jetayu

Damayanti, M., \& Latifah, L. (2015). Strategi Kota Pekalongan Dalam Pengembangan Wisata Kreatif Berbasis Industri Batik. Jurnal Pengembangan Kota, 3(2), 100. https://doi.org/10.14710/jpk.3.2.100-111

David Newsome, S. A. M. and R. K. D. (2013). Natural Area Tourism (2nd edition). CHANNEL VIEW PUBLICATIONS.
DPMPTSP Kota Pekalongan. (2021). Transportasi. DPMPTSP Kota Pekalongan. https://oss.pekalongankota.go.id/index.ph p/id/kota-pekalongan/sekilas-kotapekalongan/infrastruktur/transportasi

D’Urso, P., Disegna, M., Massari, R., \& Osti, L. (2016). Fuzzy segmentation of postmodern tourists. Tourism Management, 55, 297-308. https://doi.org/10.1016/j.tourman.2016.03. 018

Falah, M. I. F. (2018). Pesona Museum Batik Indonesia di Pekalongan. Domestic Case Study, $1-8$. https://doi.org/10.31219/osf.io/ypcsq

Falah, M. I. F. (2019). Peranan Kampong Batik Pesindon Sebagai Wisata Budaya di Pekalongan Jawa Tengah. https://doi.org/10.31219/osf.io/kxajb

Fitriani, D. (2019). Pengaruh Gender Terhadap Keputusan Pembelian Produk Online (Studi Kasus Terhadap Masyarakat Pontianak). CCIT Journal, 12(1), 99-107. https://doi.org/10.33050/ccit.v12i1.605

Fletcher, J., Fyall, A., Gilbert, D., \& Wanhill, S. (2017). Tourism : Principles and Practice Sixth Edition.

Hamzah, A., \& Khalifah, Z. (2009). Handbook on Community Based Tourism "How to Develop and Sustain CBT." Asia-Pacific Economic Cooperation Secretariat 35 Heng Mui Keng Terrace Singapore 119616.

Indonesia Kaya. (2021). Batik Pekalongan, Pesona Kaya Warna. Indonesia Kaya. https://indonesiakaya.com/pustakaindonesia/batik-pekalongan/

KAI. (2017). Stasiun Pekalongan. Unit Architecture \& Preservation. https://heritage.kai.id/page/Stasiun Pekalongan

Kartiwa, S., Ramelan, T., Asiarto, L., Boediono, A. D., Garnandi, A., Wigatna, D., Mananti, \& Ardhiati, Y. (2014). Kajian Museum Batik Indonesia. In Kementerian Pendidikan dan Kebudayaan RI (1st ed.). Direktorat Pelestarian Cagar Budaya Dan Permuseuman Direktorat Jenderal Kebudayaan. 
Kotler, P., Armstrong, G., Harris, L. C., \& He, H. (2020). Principles of MARKETING (Eight Euro). PEARSON EDUCATION LIMITED.

Matias, Á., Nijkamp, P., \& Romão, J. (2016). Impact assessment in tourism economics. In Impact Assessment in Tourism Economics. https://doi.org/10.1007/978-3319-14920-2

Matitaputty, R. A., \& Kusuma, S. S. (2017). Kuliner Khas Pekalongan (Garang Asem, Nasi Megono dan Soto Tauto). Sekolah Tinggi Pariwisata Trisakti. https://stptrisakti.ac.id/kuliner-khaspekalongangarang-asem-nasi-megonodan-soto-tauto/

Panji, A. (2018). Sejarah Asal Usul Tauto Pekalongan.

Https://Www.Cintapekalongan.Com/Sejar ah-Asal-Usul-Tauto-Pekalongan-YangKhas/.

https://www.cintapekalongan.com/sejarah -asal-usul-tauto-pekalongan-yang-khas/

Panji, A. (2020). Mengenal 4 Kopi Asli Pekalongan.

Https://Www.Cintapekalongan.Com/Men genal-Jenis-Kopi-Asli-Dari-Pekalongan/. https://www.cintapekalongan.com/menge nal-jenis-kopi-asli-dari-pekalongan/

Pantano, E., Priporas, C. V., \& Stylos, N. (2017). 'You will like it!' using open data to predict tourists' response to a tourist attraction. Tourism Management, 60, 430438.

https://doi.org/10.1016/j.tourman.2016.12. 020

Porter, M. E. (2008). Strategy the Five Competitive. Harvard Business Review, 86(January), 78-94.

Prasetiani, T. R., \& Sutrisno, C. R. (2021). ReFormulation Business Strategy Pada Umkm Industri Batik Pekalongan Memasuki Era New Normal. Jurnal Ekonomi Dan Bisnis, Vol. 24.

Sosianika, A., \& Juliani, N. (2017). Studi Tentang Perbedaan Perilaku Pembelian Impulsif Berdasarkan Karakteristik Konsumen. Jurnal Sigma-Mu, 9(1), 9-18.

Sukmasakti, A., \& Hayati, B. (2012). Strategi Pengembangan Obyek Wisata Batik Kota
Pekalongan. Diponegoro Journal of Economics, 1(1), 1-10.

Supangkat, G., Suharini, E., \& Sanjoto, T. B. (2018). Pemanfaatan Citra Satelit Untuk Menganalisis Kualitas Lingkungan Permukiman. Geo Image ( SpatialEcological-Regional ), 7(2), 123-131. http://journal.unnes.ac.id/sju/index.php/ge oimage

Taufiqurrohman, M. (2013). Strategi Pengembangan Pariwisata Serta Kontribusinya Pada Penerimaan Retribusi Kota Pekalongan. Economics Development Analysis Journal, 2(4), 446455.

Wahyuni, T., \& Zuhriyah, A. (2020). Perilaku Konsumen terhadap Keputusan Pembelian Pudak di Toko Sari Kelapa. Agriscience, 1(1), 232-243.

Widowati, I., Hartati, \& Amirudin, Z. (2018). Kemasan Makanan Kuliner Tradisional “ Megono " Sebagai Upaya Memperpanjang Waktu Simpan. Jurnal Litbang Kota Pekalongan, 15, 17-25. 